\title{
Mechanical Effect of Steel Fiber on the Cement Replacement Materials of Self-Compacting Concrete
}

\author{
Hisham Alabduljabbar ${ }^{1}$, Rayed Alyousef ${ }^{1, *} \mathbb{0}$, Fahed Alrshoudi ${ }^{2}$, Abdulaziz Alaskar ${ }^{2}$, \\ Ahmed Fathi ${ }^{3}$ (D) and Abdeliazim Mustafa Mohamed ${ }^{1}$ (D) \\ 1 Department of Civil Engineering, College of Engineering, Prince Sattam bin Abdulaziz University, \\ Al-kharj 11942, Saudi Arabia; h.alabduljabbar@psau.edu.sa (H.A.); a.bilal@psau.edu.sa (A.M.M.) \\ 2 Department of Civil Engineering, College of Engineering, King Saud University, Riyadh 11362, Saudi Arabia; \\ falrshoudi@ksu.edu.sa (F.A.); Abalaskar@ksu.edu.sa (A.A.) \\ 3 Department of Civil Engineering, College of Engineering, University of BISHA, Bisha 61922, Saudi Arabia; \\ alahmdy665@gmail.com \\ * Correspondence: r.alyousef@psau.edu.sa; Tel.: +96-65-0510-6558
}

Received: 18 February 2019; Accepted: 18 April 2019; Published: 25 April 2019

check for updates

\begin{abstract}
The behaviors of the fresh and mechanical properties of self-compacting concrete (SCC) are different from those of normal concrete mix. Previous research has investigated the benefits of this concrete mix by incorporating different constituent materials. The current research aims to develop a steel fiber reinforcement (SFR)-SCC mixture and to study the effectiveness of different cement replacement materials (CRMs) on the fresh and mechanical properties of the SFR-SCC mixtures. CRMs have been used to replace cement content, and the use of different water/cement ratios may lower the cost of CRMs, which include microwave-incinerated rice husk ash, silica fume, and fly ash. Fresh behavior, such as flow and filling ability and capacity segregation, was examined by a special test in SCC on the basis of their specifications. Moreover, compressive and splitting tensile strength tests were determined to simulate the hardened behavior for the concrete specimens. Experimental findings showed that, the $V$-funnel and $L$-box were within the accepted range for SCC. Tensile and flexural strength increases upon the use of $10 \%$ silica fume were found when compared with other groups; the ideal percentage of steel fiber that should be combined in this hybrid was $2 \%$ of the total weight of the binder. Overall, steel fibers generated a heightened compressive and splitting tensile strength in the self-compacting concrete mixes.
\end{abstract}

Keywords: self-compacting concrete; steel fiber; cement materials; microwave-incinerated rice husk ash

\section{Introduction}

New concrete materials, such as self-compacting concrete (SCC), can prevent the segregation of their constituents and allow the concrete to flow easily under its weight and not by concrete vibrator. SCC properties have been studied in the context of solving the workability defects of ordinary concrete, such as the low slump value [1-3]. To achieve this type of concrete mix and enhance the flow ability [4-6] the amount of cement should be increased, aggregate should be minimized, and concrete admixture should be added. However, increasing the cement content will make the concrete brittle, resulting in the failure of the concrete member and an increase in production costs. The use of steel fibers in SCC-containing cement replacement materials (CRMs) will enhance its strength, increase the mechanical properties and durability of concrete structures, and bridge any cracks. Cementing materials can replace at least part of the cement on the condition that the CRM has the same properties as cement, thereby minimizing the total cost [7-9]. The effects of the addition of fiber-reinforced self-compacting 
concrete (FR-SCC) are not fully determined at present, but there is some evidence that reinforced fiber has been reported to improve the flexural and shear strength, ductility and toughness of cementitious replacement materials. Fibers cracks in bridge during load transferring, arrest the coalescence and growth of the cracks, and play the important role of the absorption of energy [10-12]. Fiber is commonly added to provide better tensile and flexural strength and for the concrete crack controlling, to reduce the cracks coalescence, and to diversification behavior of the material by the placing of fibers across the concrete cracks. In a different manner, ductility is returned with reinforced fiber cementation composites due to the reinforced fibers bridge the cracked surface and deferment the extension of a localized crack. The fiber takes the internal stress through the resistance of tension and ensures the loads transferring, creating a better bond between the hardened cement matrix and reinforced fiber. The main application of reinforced concrete steel fiber is in elements undergo to a potentially damaging dynamic load and a concentrated load. Steel fiber reinforced concrete has been recently used in many industrial and infrastructure application areas, like in industrial flooring, pavements in the airport, overlay, and lining of channel $[13,14]$. The main disadvantage of fibers when they are added to a concrete mix is clumping, as fibers could attach directly before they are compiled to the mixture or during the mixing process; moreover, normal mixing action will not break apart these clumps. The fly ash type of CRMs is used in concrete mixtures as a replacement for cement to enhance the properties of SCC, such as workability [15-18]. Various replacement percentages of fly ash in SCC have been studied to determine the maximum improvement and optimum replacement percentage of the added fly ash [19-21]. Nuruddin et al. investigated microwave-incinerated rice husk ash (MIRHA) and reported a high microporous silica content. The aforementioned study concluded that the use of microwave-incinerated rice husk ash would strengthen SCC depending on its amorphous silica content, which can be expected from a good burning of the rice husk into ash [22-24]. The use of silica fume in SCC can improve the workability of SCC and increase the compressive strength [25-27]. In a recent work [28], presenting the addition of FRC systems combined with high stiffness steel fiber and low stiffness steel fiber in macro-synthetic concrete, there was a slight increase in the air voids with the addition of steel fiber up to the $1 \%$ of volume fraction, and reduced workability, causing greater increases in the concrete stiffness compared with the control specimen. The effect of ultra-high-strength micro steel fibers of reinforced concrete containing under active confinement is reported in [29], the finding showing that the axial stress and strain of steel fiber reinforced concrete (SFRC) at a given stress and lateral strain growing with an increase in the amount fraction, indicating a decreased rate of dilation of steel fiber reinforced concretes at a larger amount fraction. The influence of aspect ratio and amount of fibers on shear strength behavior of reinforced concrete steel fiber was investigated by [30], with the test findings for concretes C30 and for C50 indicating that as the volume fraction of fibers increased from 0 to 1.5 percent, the shear strength increased to about 2.15 and 2.46 times that of plain concrete, respectively. In addition, the aspect ratio and amount of steel fibers had no direct effect on the concrete shear strength. Moreover, observation of steel fibres in concrete with computed tomography showed that the same volume fraction of steel fibers and longer mixing time provided better tensile and flexural strength values, and the residual tensile-flexural strength increased with an increase in the fiber content [31]. The effect of fiber on the high-performance fiber-reinforced concrete presented by [32] showed that the addition of steel fibers in high-performance concrete (HPC) improves the mechanical behaviors of concrete, particularly the tensile strength (TS), flexural strength (FS), and ductility properties. Finally, the same study reported that fibrous beams show improved overall shear performance as they exhibited improved shear strengths, energy dissipation capacities and ultimate deflections compared with the control samples.

The present work deals with the use of steel fibers on the cement replacement materials of self-compacting concrete to enhance the strength and durability of concrete. In addition, the main aims of the current study were to develop steel fiber reinforcement (SFR)-SCC and determine the effectiveness of different CRMs on the fresh and mechanical properties of the SFR-SCC mixs. Four different mixes of self-compacting concrete containing CRMs were examined to study the effectiveness of different CRM 
on the fresh and mechanical properties of SFR-SCC mixtures, focusing on the slump flow, $V$-funnel and L-box tests, splitting tensile, and flexural strength of the SFR-SCC mixes. The final objective of this work was to determine the optimum percentage of steel fibers that can be added to concrete to enhance its properties. However, research work investigating the effect of CRMs on the properties of SCC is rare. Most of the previous research work on the utilization of fiber reinforcement focuses on using steel fibers to improve the tensile nature of concrete or cement only to improve the durability of concrete. Using combined steel fibers as reinforcement and CRMs to improve the strength and increase the mechanical properties and durability of concrete, providing ductility with fiber reinforced cementation composites, creating a good bond between the fiber and hardened cement matrix, and reducing the shrinkage and porosity of concrete are all factors that have also not been frequently reported in the research.

\section{Methods}

\subsection{Materials}

Ordinary Portland cement (OPC) Type-I was used in this tests. Table 1 shows the chemical characteristics of ordinary cement. All the materials used in this study were obtained from Saudi Arabia such as fly ash (class F) following the British Standard EN 450.1995. Silica fume (see Table 1 for the chemical composition) was the second type of pozzolanic material selected to replace part of the cement. This material was obtained from the Elkem material section in a dry powder form, grade $920 \mathrm{E}$, with under $4 \%$ of silica fume and areas of $15 \mathrm{~m}^{2} / \mathrm{g}$ to $35 \mathrm{~m}^{2} / \mathrm{g}$ based on ASTM C1240. Figure 1 shows the materials (ordinary Portland cement, fly ash, silica fume, microwave incinerated rice husk ash, superplasticizer, and straight steel fiber) used for the experiment. The microwave incinerated husk ash were collected by burning rice husk ash (RHA) at $800^{\circ} \mathrm{C}$ in a microwave incinerator. We used high-quality straight steel fibers, as shown in Figure $1 \mathrm{H}$. The fine aggregate used in this study was natural fine aggregate (sand) with a maximum nominal size of $3.35 \mathrm{~mm}$, specific gravity of 2.61, and a fineness modulus of 2.76. Crushed granite stone was used as the coarse aggregate with a nominal maximum size between 5 to $10 \mathrm{~mm}$ with a specific gravity of 2.66 in the surface saturated condition based on BS 812-103.21989. Table 2 presents the aggregates. A SIKA-KIMIA superplasticizer as admixture was used to increase the concrete workability mixture. The effective liquid superplasticizer complied with the requirement of BS 5075.WSF 0220. High-strength steel with a diameter of $0.2 \mathrm{~mm}$, length of $20 \mathrm{~mm}$, and aspect ratio of 100 was used in this experiment. The tensile strength was over $2300 \mathrm{MPa}$, which conforms with ASTM A 820 and EN 14889.

Table 1. Chemical characteristics of cement.

\begin{tabular}{ccccc}
\hline $\begin{array}{c}\text { Chemical } \\
\text { Elements }\end{array}$ & $\begin{array}{c}\text { Ordinary Portland } \\
\text { Cement (OPC) } \\
(\mathbf{\%})\end{array}$ & $\begin{array}{c}\text { Fly Ash } \\
(\mathbf{\%})\end{array}$ & $\begin{array}{c}\text { Microwave-Incinerated Rice } \\
\text { Husk Ash (MIRHA) } \\
(\%)\end{array}$ & $\begin{array}{c}\text { Silica Fume } \\
(\%)\end{array}$ \\
\hline $\mathrm{SiO}_{2}$ & 20.3 & 56.39 & 90.75 & 96.36 \\
$\mathrm{Al}_{2} \mathrm{O}_{3}$ & 4.2 & 17.57 & 0.75 & 0.21 \\
$\mathrm{Fe}_{2} \mathrm{O}_{3}$ & 3 & 9.07 & 0.28 & 0.77 \\
$\mathrm{CaO}$ & 62 & 11.47 & 0.87 & 0.24 \\
$\mathrm{MgO}$ & 2.8 & 0.98 & 0.63 & 0.52 \\
$\mathrm{SO}$ & 3.5 & 0.55 & 0.33 & 0.55 \\
$\mathrm{~K}_{2} \mathrm{O}$ & 0.9 & 1.98 & 3.77 & 0.102 \\
$\mathrm{Na}_{2} \mathrm{O}$ & 0.2 & 1.91 & 0.02 & 0.12 \\
\hline
\end{tabular}




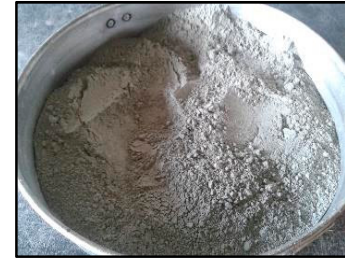

(A) Ordinary Portland Cement

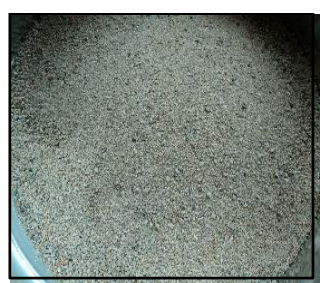

(E) Fine Aggregate

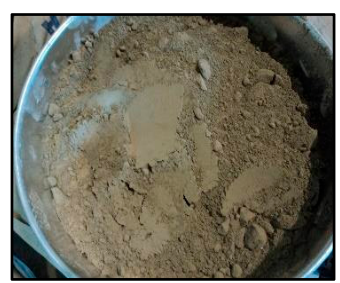

(B) Fly ash

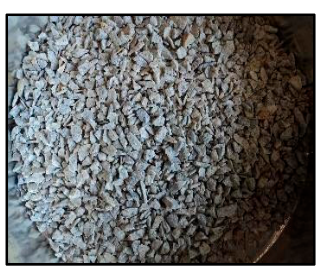

(F) Coarse Aggregate

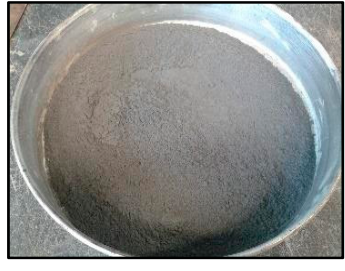

(C) Silica Fume

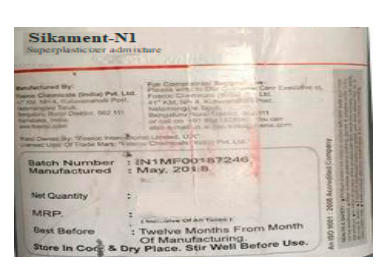

(G) Superplasticizer

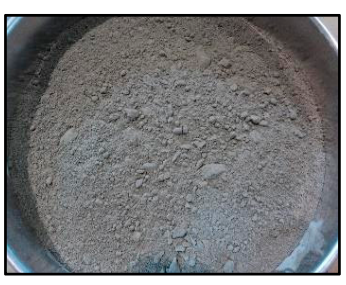

(D) Microwave Incinerated Rice Husk Ash

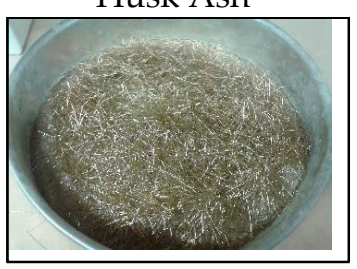

(H) Steel Fiber

Figure 1. Materials used in the experiment.

Table 2. Grading of the coarse and fine aggregates.

\begin{tabular}{ccc}
\hline $\begin{array}{c}\text { Sieve Size } \\
(\mathbf{m m})\end{array}$ & $\begin{array}{c}\text { Fine Aggregate } \\
\text { Passing } \mathbf{( \% )}\end{array}$ & $\begin{array}{c}\text { Coarse Aggregate } \\
\text { Passing } \mathbf{( \% )}\end{array}$ \\
\hline 10.00 & 91.3 & - \\
5.00 & 85.4 & - \\
3.35 & 68.5 & 56.8 \\
2.36 & 46.8 & 50.3 \\
2.00 & 33.3 & 39.2 \\
1.18 & 18.6 & 23.4 \\
0.60 & 7.9 & 11.5 \\
0.30 & - & 7.3 \\
0.21 & - & 4.7 \\
0.15 & - & 1.3 \\
Pan & 0 & 0 \\
\hline
\end{tabular}

\subsection{Mix Design and Proportion}

Sixteen concrete mixes were prepared with different percentages of SFR-SCC and divided into four groups. The groups were named Mix-C, Mix-FA, Mix-MR, and Mix-SF, as shown in Table 3. Each group consisted of four different volumes of straight steel fiber at $0 \%, 1 \%, 1.5 \%$, and $2 \%$ of the total binder. The cement content, superplasticizer, and fine and coarse aggregates were kept constant at $600,12,900$, and $750 \mathrm{~kg} / \mathrm{m}^{3}$. In the first mixture, all the cement $(100 \%)$ was ordinary Portland cement. After mixing, the fresh properties of the SRF-SCC mixes were examined using $L$-box, $V$-funnel, and slump flow (slump T50). Compressive strength was tested for 7, 28, and 90 days, while tensile and flexural strength were tested for 28 days, and thereafter, all specimens were molded. Cubes of $100 \mathrm{~mm} \times 100 \mathrm{~mm}$ in size were prepared for the compressive strength test, while prisms had a size of $400 \mathrm{~mm} \times 100 \mathrm{~mm} \times 100 \mathrm{~mm}$. After the process, all specimens were demolded and submerged in a curing tank until the day of the concrete tests to determine the hardened properties of the SFR-SCC mixes. The results were compared using the specifications of the European Federation of Producers and Applicator of Specialist Products for structure (EFNARC) [33,34]. 
Table 3. Presentation of the admixture proportions.

\begin{tabular}{|c|c|c|c|c|c|c|c|c|c|c|c|}
\hline \multirow{2}{*}{$\begin{array}{l}\text { Mixture } \\
\text { Name }\end{array}$} & \multirow[t]{2}{*}{ Code Mix } & \multicolumn{4}{|c|}{ Binder Formation \% } & \multicolumn{4}{|c|}{$\begin{array}{c}\text { Binder Content } \\
\mathrm{Kg} / \mathrm{m}^{3}\end{array}$} & \multirow{2}{*}{$\begin{array}{l}\text { Water } \\
\mathrm{kg} / \mathrm{m}^{3}\end{array}$} & \multirow{2}{*}{$\begin{array}{l}\text { Steel } \\
\text { Fiber } \%\end{array}$} \\
\hline & & OPC & FA & MR & SF & OPC & FA & MR & SF & & \\
\hline \multirow{4}{*}{ Mix-C } & C-SO & 100 & 0 & 0 & 0 & 600 & 0 & 0 & 0 & 200 & 0 \\
\hline & C-S1 & 100 & 0 & 0 & 0 & 600 & 0 & 0 & 0 & 200 & 1 \\
\hline & C-S2 & 100 & 0 & 0 & 0 & 600 & 0 & 0 & 0 & 200 & 1.5 \\
\hline & C-S3 & 100 & 0 & 0 & 0 & 600 & 0 & 0 & 0 & 200 & 2 \\
\hline \multirow{4}{*}{ Mix-FA } & FA-S0 & 70 & 30 & 0 & 0 & 420 & 180 & 0 & 0 & 196 & 0 \\
\hline & FA-S1 & 70 & 30 & 0 & 0 & 420 & 180 & 0 & 0 & 196 & 1 \\
\hline & FA-S2 & 70 & 30 & 0 & 0 & 420 & 180 & 0 & 0 & 196 & 1.5 \\
\hline & FA-S3 & 70 & 30 & 0 & 0 & 420 & 180 & 0 & 0 & 196 & 2 \\
\hline \multirow{4}{*}{ Mix-MR } & MR-S0 & 90 & 0 & 10 & 0 & 540 & 0 & 60 & 0 & 209 & 0 \\
\hline & MR-S1 & 90 & 0 & 10 & 0 & 540 & 0 & 60 & 0 & 209 & 1 \\
\hline & MR-S2 & 90 & 0 & 10 & 0 & 540 & 0 & 60 & 0 & 209 & 1.5 \\
\hline & MR-S3 & 90 & 0 & 10 & 0 & 540 & 0 & 60 & 0 & 209 & 2 \\
\hline \multirow{4}{*}{ Mix-SF } & SF-S0 & 90 & 0 & 0 & 10 & 540 & 0 & 0 & 60 & 192 & 0 \\
\hline & SF-S1 & 90 & 0 & 0 & 10 & 540 & 0 & 0 & 60 & 192 & 1 \\
\hline & SF-S2 & 90 & 0 & 0 & 10 & 540 & 0 & 0 & 60 & 192 & 1.5 \\
\hline & SF-S3 & 90 & 0 & 0 & 10 & 540 & 0 & 0 & 60 & 192 & 2 \\
\hline
\end{tabular}

Note: For all concrete mixes, Crushed granite $=750 \mathrm{~kg} / \mathrm{m}^{3}$, sand $=900 \mathrm{~kg} / \mathrm{m}^{3}$, and superplasticizer $=12 \mathrm{~kg} / \mathrm{m}^{3}$; OPC: ordinary Portland cement, C: control specimen, FA: Fly ash, MR: microwave-incinerated rice husk ash, SF: silica fume.

\subsection{Experimental Procedure}

The methodology of this study involved testing the fresh and hardened properties of the specimens, such as their compressive, flexural, and tensile strength. These properties could be tested if the freshness requirement was determined on the basis of the EFNARC. The SCC mixes were prepared using a concrete mixer. However, cement was replaced by $30 \%$ fly ash, 10\% MIRHA, and 10\% silica fume in the second, third, and fourth mixtures, respectively, on the basis of the literature $[4,7,11]$. First, the aggregate was washed using clean water. Second, the fine and coarse aggregates were mixed with half amount of the water and left for $120 \mathrm{~s}$ to complete the absorption. Third, the mineral admixture and cement were added to the remaining water. The superplasticizer was left for $4 \mathrm{~min}$ to allow the chemical reaction of the admixture to complete. Lastly, steel fibers were added to the concrete mixer and mixed for $4 \mathrm{~min}$ to provide an improved distribution of the steel fiber in the concrete mixture. The cubes and cylindrical specimens were casted and kept at room temperature $\left(20^{\circ} \mathrm{C}\right)$ for $24 \pm 1 \mathrm{~h}$ after the casting time. After the removal of the specimens from the mold, they were submerged in the curing tank for curing until the specified age of the specimen test. The samples were examined under a saturated surface dry condition (SSD) following the BS I881. Part 114. For the slump test, the cone was packed with concrete and lifted vertically as the time measurement began. The $V$-funnel experiment was used to examine the viscosity of self-compact concrete. The experiment was performed by filling a funnel with approximately $12 \mathrm{~L}$ of concrete. The time in seconds was measured to show how long the concrete took to empty out from the funnel. The $L$-box test was performed by filling the vertical part of the equipment. The three steel reinforcements were removed to allow the mix to pass through it and fill the horizontal portion of the L-box. The time the SCC mix took to reach the horizontal part was also measured.

\section{Results and Discussion}

\subsection{Fresh Properties}

To assess the capacity of SCC for flow ability, slump flow, $L$-box, and $V$-funnel tests were performed on fresh properties of SCC. Figures $2-4$ show the fresh workability of the SFR-SCC mixes. The outcomes of these tests revealed that the 16 mixes of SCC possessed beneficial filling and passing abilities and segregation resistance. Steel fiber slightly decreased the slump flow diameter and slump T50. Mix-FA (Figure 2), which contained 30\% fly ash, recorded higher slump results with no bleeding and 
segregation compared with those of the silica fume and MIRHA. The $V$-funnel results indicated that the steel fibers did not affect the viscosity of the SFR-SCC mixes. The majority of the SCC mixes in the $V$-funnel test results were within the 6 to $12 \mathrm{~s}$ range, as mentioned in the EFNARC. The results of the $L$-box test indicated that the three types of CRMs enhanced the SFR-SCC mixes' resistance to segregation. Segregation and bleeding were not observed, but the slump value was decreased because of the higher fiber concentration. However, the steel fibers only slightly decreased this resistance because all the mixes showed results acceptable to the EFNARC.
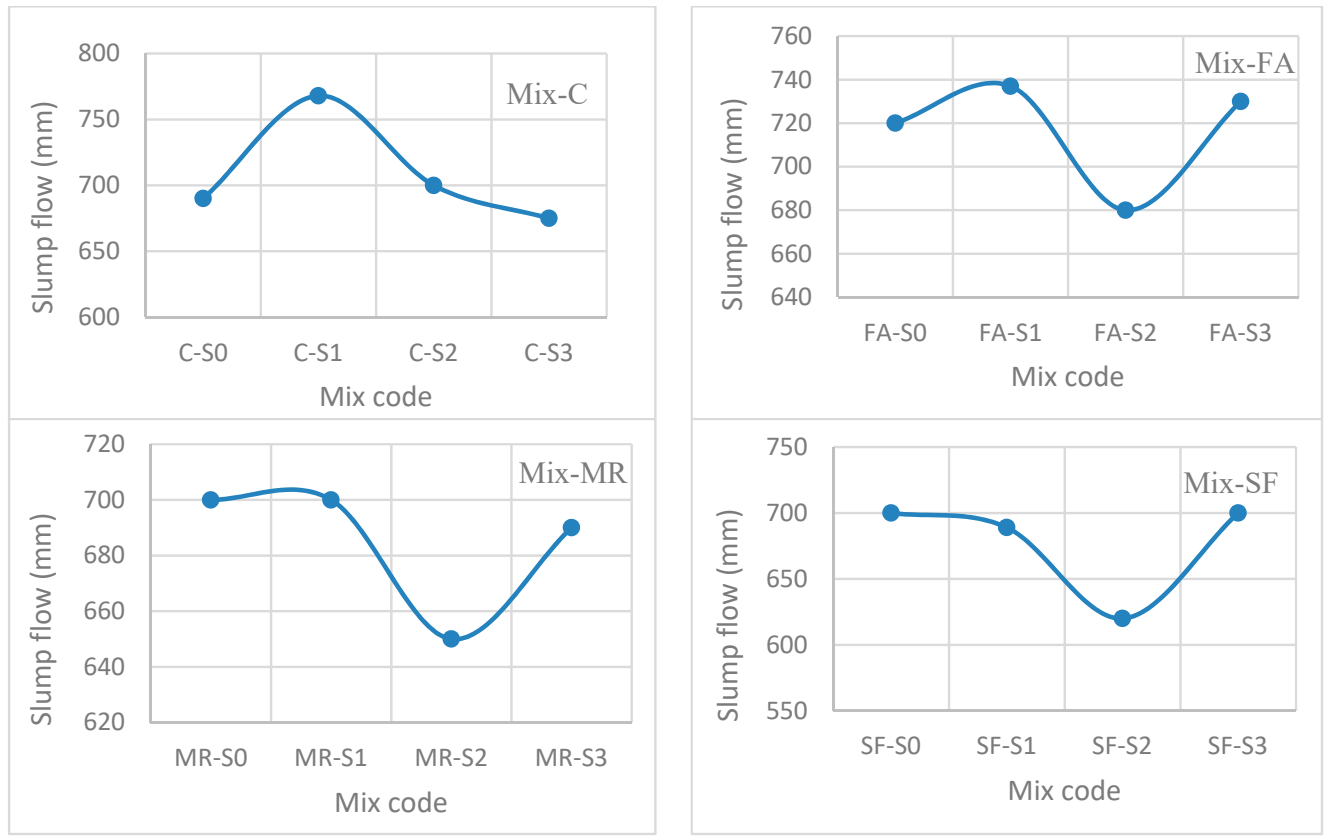

Figure 2. Slump flow results of all steel fiber reinforcement-self-compacting concrete (SFR-SCC) groups.
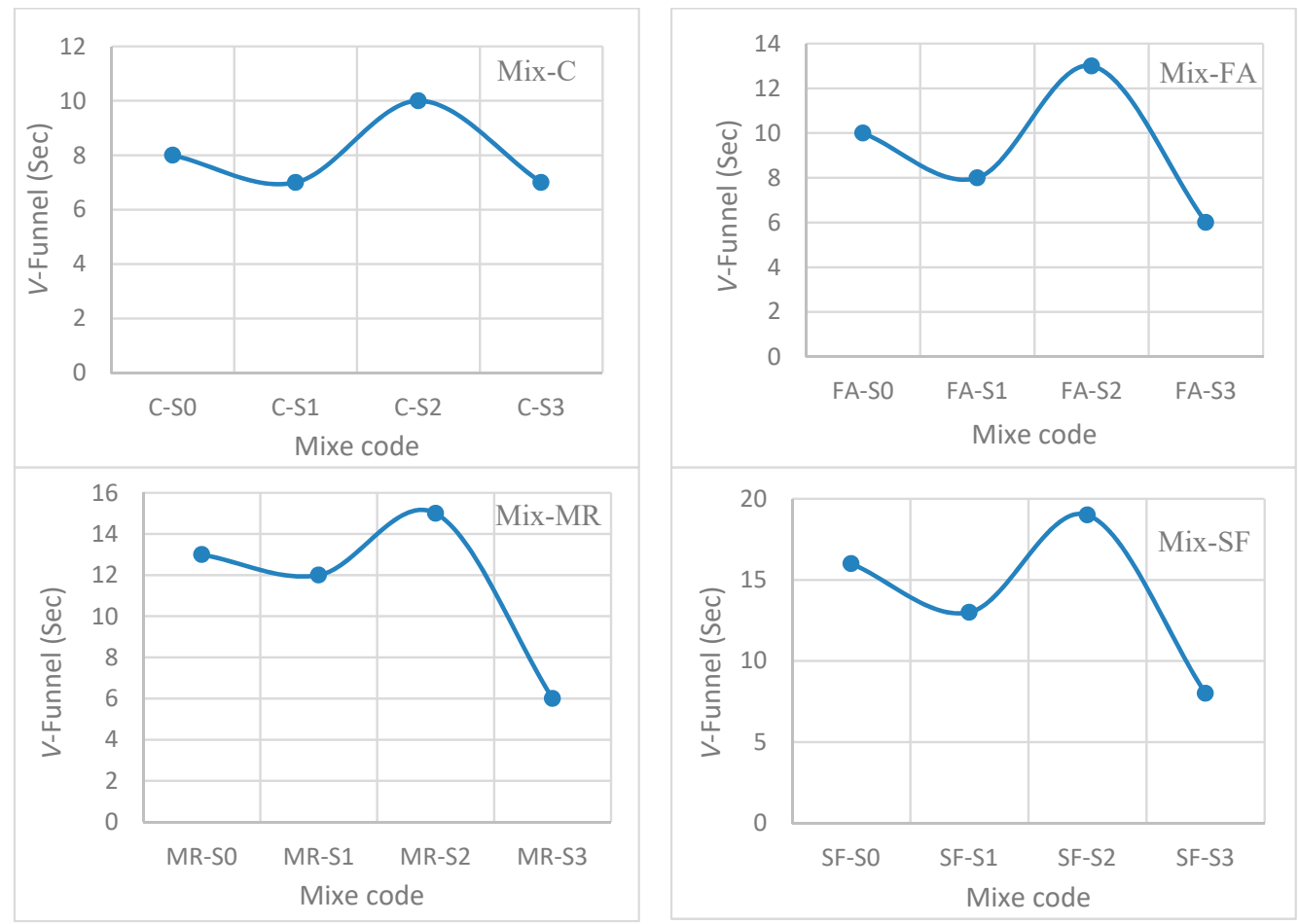

Figure 3. $V$-funnel results of all SFR-SCC groups. 

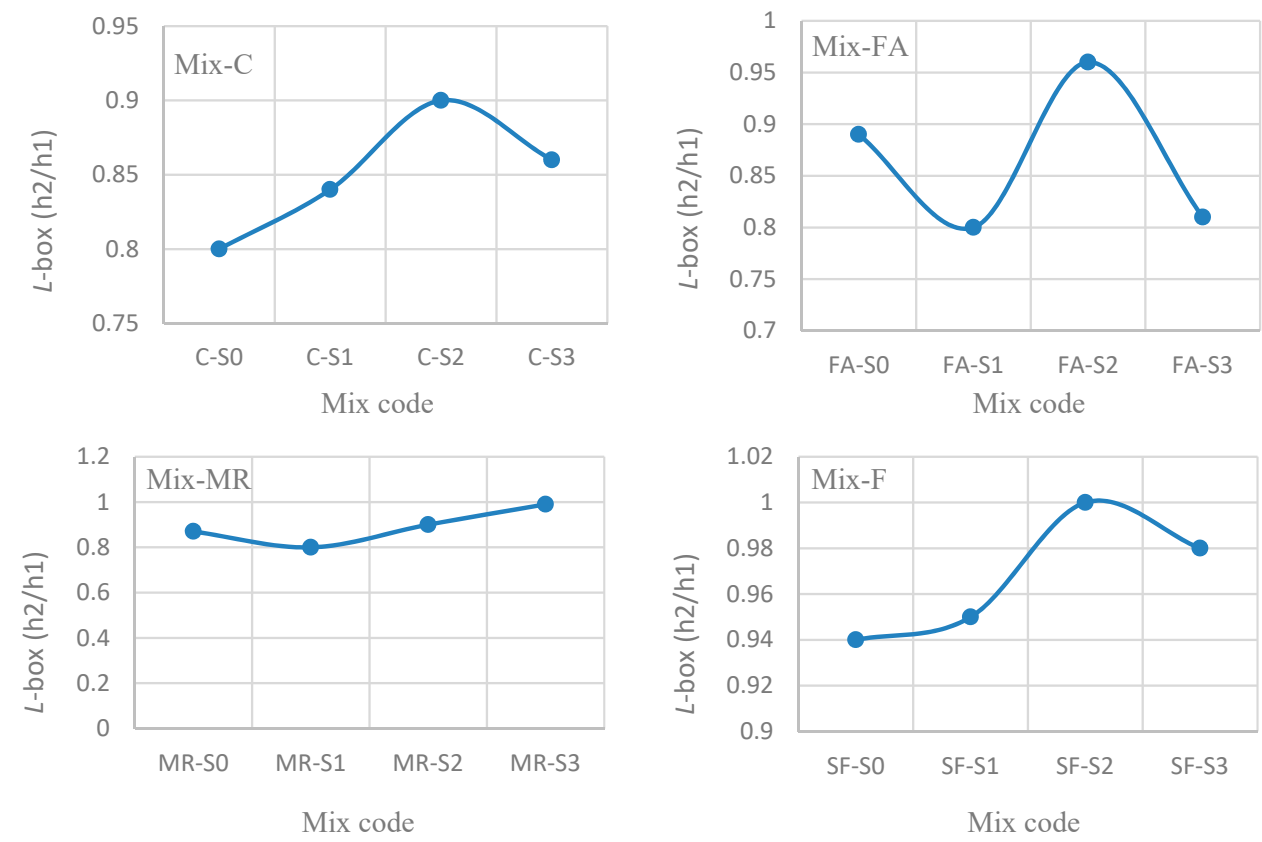

Figure 4. L-box results of all SFR-SCC groups.

\subsection{Compressive Strength}

Compressive strength experiment was determined for 7, 28, and 90 days, as presented in Figure 5, and was determined according to the BS 1881: Part 116:1983. Three specimens were casted for each test, and the average was calculated. The findings indicated that the mix of $10 \%$ silica fume gained higher strength compared with the other groups. The steel fibers gradually increased the strength of all the mixes. This finding is consistent with the results of previous research on the contribution of steel fiber to the compressive strength of concrete [35-40]. Overall, $2 \%$ of steel fiber by weight was the optimum for the majority of the groups. Figure 4 shows that Mix-MR, which includes $10 \%$ of MIRHA, had a lower strength compared with Mix-C of $100 \%$ ordinary Portland cement (OPC). The compressive strength of the mix with MIRHA after seven days was lower than the mix with $100 \%$ OPC. After 28 and 90 days, the strength values were comparable. MIRHA provided a less fine microstructure and higher porosity compared with the silica fume and fly ash.

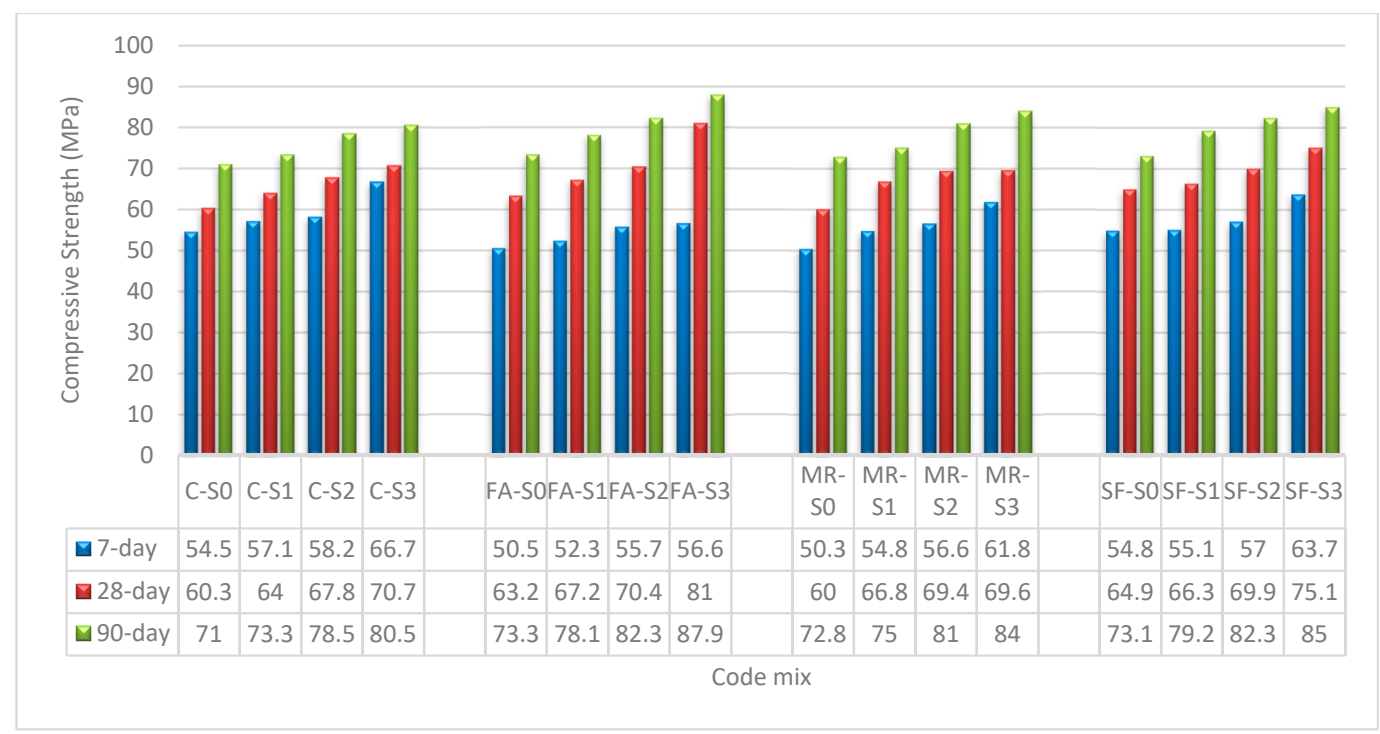

Figure 5. Compressive strength test at 7, 28, and 90 days. 


\subsection{Splitting Tensile Strength}

The concrete cylinder samples with length of $20 \mathrm{~cm}$ and a diameter of $10 \mathrm{~cm}$ were cast for testing in the age of curing range between 28 and 90 days on the basis of BS 1881: Part 117:1983. Sample Mix-FA achieved a higher splitting tensile strength on the 90th day of the test, and thereafter the strength started decreasing for Mix-MR and Mix-SF at the same curing. The 1.5\% of steel fibers with $30 \%$ fly ash recorded a high result of $10.8 \mathrm{MPa}$ for 3 months. The $2 \%$ of steel fibers with $100 \%$ cement showed $8.95 \mathrm{MPa}$ as the highest strength for 28 days. Figure 6 shows that the steel fibers increased the splitting tensile strengths by $91.6 \%$ and $51.1 \%$ as the maximum and minimum, respectively. The results presented in Figure 6 reveal no significant difference in the effects of the CRM types, though $30 \%$ fly ash with steel fibers had a slightly greater effect than the others. This could have resulted from the addition of steel fiber that fit into the concrete matrix and thus produced the highest density. This is consistent with [41], which reported that the splitting tensile strength was influenced by the density of concrete.

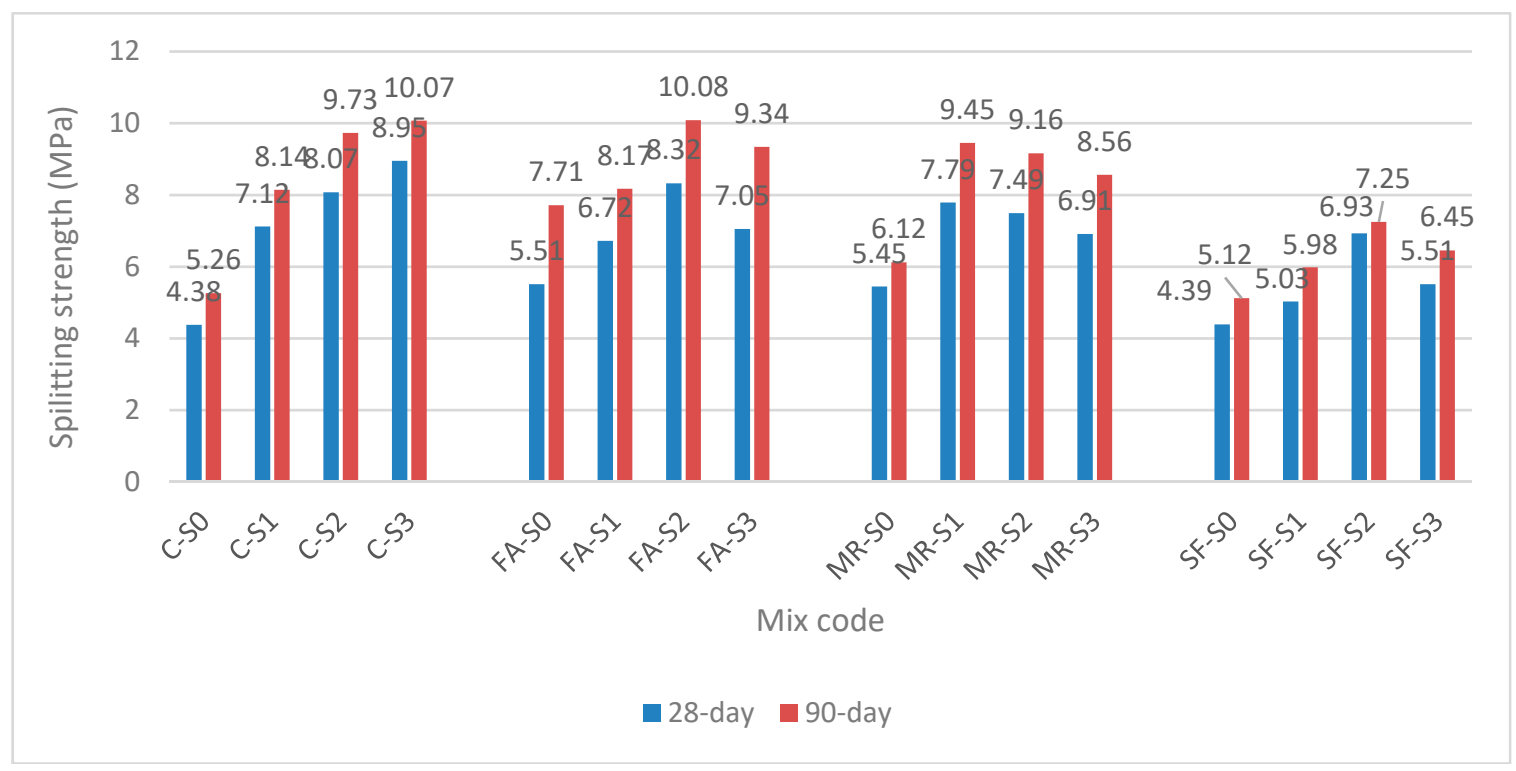

Figure 6. Splitting strength test at 28 and 90 days.

\subsection{Flexural Strength}

Concrete beams sized $10 \mathrm{~cm} \times 10 \mathrm{~cm} \times 50 \mathrm{~cm}$ were casted and checked after 28 days to highlight the flexural property of a concrete mix on the basis of BS1881: Part 117:183. The results of the flexural strength test indicated that the addition of fiber could enhance this property. Figure 7 shows that the steel fiber with silica fume in Mix-SF gained flexural strength (an increase from 10.8 to 12.3 MPa) compared with the other mixes (Mix-C, Mix-SF, and Mix-MR), which increased as follows: $1.9,9.6$, and 4.9 MPa, respectively. Hence, adding $2.0 \%$ steel fiber in all groups improved flexural strength. This is because the improvement in the flexural strength of concrete was due to the increased fiber-matrix bond provided with the reinforced steel fibers [42]. The finding is compatible with the results in [13]. For the effect of binder on the flexural behavior, using $10 \%$ silica fume in the concrete mix could increase the flexural values compared with other groups. 


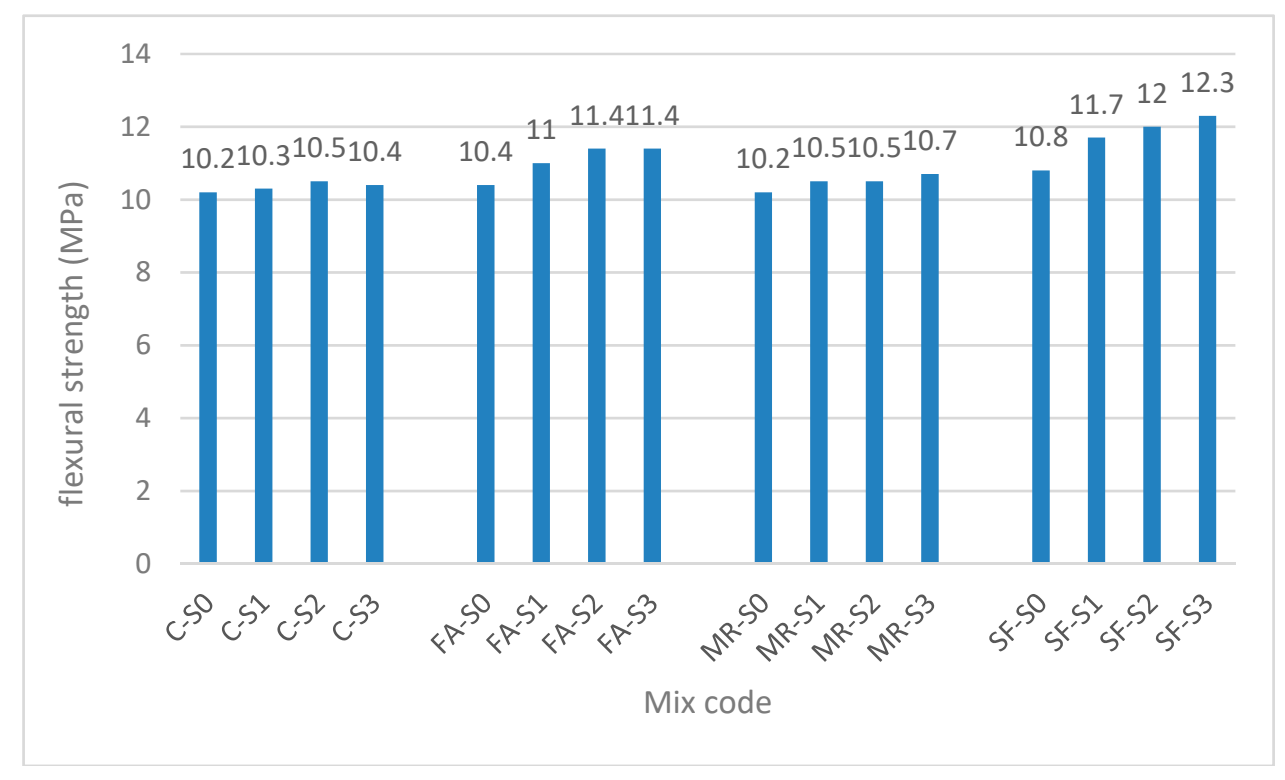

Figure 7. Flexural strength test at 28 days.

The indirect splitting tensile and flexural strengths are special measures of splitting tensile strength. As predicted, they were significantly different in quantity; however, they were found to follow almost the same direction of variation as a function of CRMs and steel fiber amounts. This is explained by their linear correlation, illustrated by the relationship proposed in [43].

\section{Conclusions}

The study presented in the paper used different CRMs and steel fibers to improve tensile strength and durability of SFR-SCC. The results of the study are as follows:

- The workability of SFR-SCC was enhanced by the choice of CRM types. Furthermore, the straight length was found to mitigate a substantial variation in slump flow, indicating the negative impact of steel fibers on the $V$-funnel and $L$-box behaviors. Additionally, $9 \%$ improvement in workability was reported for Mix-FA in comparison with Mix-C, Mix-MR, and Mix-SF with no bleeding and segregation. Meanwhile, in similar settings, i.e., the absence of bleeding and segregation, lower slump values were observed for Mix-SF samples associated with higher fiber concentrations.

- In terms of strength properties, a higher compressive strength of up to $19 \%$ at 28 days was observed for Mix-FA, while the other Mix-C, Mix-MR, and Mix-SF concrete samples showed declines in similar strength properties. Similarly, the Mix-SF sample achieved higher flexural strength of up to $13 \%$ around the 28 th day of the test, while Mix-C, Mix-MR, and Mix-SF exhibited a decline in flexural strength within the same interval.

- The trend continued in terms of the tensile strength of the concrete samples, which varied proportionally with fiber quantity for all concrete mixtures. Overall, the experiments reported in the study corroborated the expectation that steel fiber would enhance the strength properties of concrete. A $2 \%$ concentration of steel fiber was found to be the optimum amount that could be added to the SFR-SCC mixes.

- Finally, whereas maximum strength properties were observed in fly ash mixes at 28 and 90 days, at the same period, steel fibers were found to substantially enhance the splitting tensile strength for all the SFR-SCC samples, and compressive strength tests showed that the choice of CRM type did not affect the strength of the concrete.

- Further investigations can be determined in these properties, and the effect of steel fiber on the CRMs of SCC and their dependence on the binder content are issues that remain to be addressed in future investigations. 
Author Contributions: Conceptualization, H.A. and R.A.; methodology, A.F.; validation, F.A., A.A.; investigation, A.M.M.; writing, H.A., F.A., A.A. and R.A. Review and editing, R.A. and A.M.M. Funding acquisition, R.A., H.A., F.A., A.A. and A.M.M.

Funding: This research received no external funding and the APC was funded by Rayed Alyousef.

Acknowledgments: The authors gratefully acknowledge the technical and financial support from the corporation of the Research Center of College of Engineering, Deanship of Scientific Research (DSR), King Saud University, Saudi Arabia; and the Department of Civil Engineering, Prince Sattam Bin Abdulaziz University, Saudi Arabia.

Conflicts of Interest: The authors declare there is no conflict of interest reading the publication of this paper.

\section{References}

1. Okamura, H.; Ouchi, M. Self-compacting concrete. J. Adv. Concr. Technol. 2003, 1, 5-15. [CrossRef]

2. Persson, B. A comparison between mechanical properties of self-compacting concrete and the corresponding properties of normal concrete. Cem. Concr. Res. 2001, 31, 193-198. [CrossRef]

3. Wang, S.; Li, V.C. Polyvinyl alcohol fiber reinforced engineered cementitious composites: Material design and performances. In Proceedings of the International Workshop on HPFRCC Structural Applications, Honolulu, HI, USA, 23-26 May 2005.

4. Ferrara, L.; Park, Y.-D.; Shah, S.P. A method for mix-design of fiber-reinforced self-compacting concrete. Cem. Concr. Res. 2007, 37, 957-971. [CrossRef]

5. De Schutter, G.; Gibbs, J.; Domone, P.; Bartos, P.J. Self-Compacting Concrete; Whittles Publishing: Caithness, Scotland, 2008.

6. Okamura, H.; Ozawa, K. Mix design for self-compacting concrete. Concr. Libr. JSCE 1995, 25, 107-120.

7. Mohamed, N.S.A.F.; Nuruddin, M.F. Ali Elheber Effect of Silica Fume on the Properties of Steel Fiber Reinforced Self-compacting Concrete. World Acad. Sci. Eng. Technol. Int. J. Civ. Eng. 2013, 7, 856-860.

8. Horszczaruk, E. Hydro-abrasive erosion of high performance fiber-reinforced concrete. Wear 2009, 267, 110-115. [CrossRef]

9. Horikoshi, T.; Ogawa, A.; Saito, T.; Hoshiro, H.; Fischer, G.; Li, V. Properties of Polyvinylalcohol fiber as reinforcing materials for cementitious composites. In Proceedings of the International RILEM Workshop on HPFRCC in Structural Applications, Honolulu, HI, USA, 6 May 2006; p. 147.

10. Su, N.; Hsu, K.-C.; Chai, H.-W. A simple mix design method for self-compacting concrete. Cem. Concr. Res. 2001, 31, 1799-1807. [CrossRef]

11. Fathi, A.; Shafiq, N.; Nuruddin, M.; Elheber, A. study the effectiveness of the different pozzolanic material on self-compacting concrete. J. Eng. Appl. Sci. 2013, 8, 201.

12. Şahmaran, M.; Christianto, H.A.; Yaman, I. Özgür the effect of chemical admixtures and mineral additives on the properties of self-compacting mortars. Cem. Concr. Compos. 2006, 28, 432-440. [CrossRef]

13. Aydin, A.C. Self compactability of high volume hybrid fiber reinforced concrete. Constr. Build. Mater. 2007, 21, 1149-1154. [CrossRef]

14. Boulekbache, B.; Hamrat, M.; Chemrouk, M.; Amziane, S. Flowability of fibre-reinforced concrete and its effect on the mechanical properties of the material. Constr. Build. Mater. 2010, 24, 1664-1671. [CrossRef]

15. Corinaldesi, V.; Moriconi, G. Durable fiber reinforced self-compacting concrete. Cem. Concr. Res. 2004, 34, 249-254. [CrossRef]

16. Corinaldesi, V.; Moriconi, G. Characterization of self-compacting concretes prepared with different fibers and mineral additions. Cem. Concr. Compos. 2011, 33, 596-601. [CrossRef]

17. Hossain, K.M.A.; Lachemi, M.; Sammour, M.; Sonebi, M. Influence of Polyvinyl Alcohol, Steel, and Hybrid Fibers on Fresh and Rheological Properties of Self-Consolidating Concrete. J. Mater. Civ. Eng. 2012, 24, 1211-1220. [CrossRef]

18. Lee, B.Y.; Kim, J.-K.; Kim, J.-S.; Kim, Y.Y. Quantitative evaluation technique of Polyvinyl Alcohol (PVA) fiber dispersion in engineered cementitious composites. Cem. Concr. Compos. 2009, 31, 408-417. [CrossRef]

19. Kanda, T.; Li, V.C. Effect of Fiber Strength and Fiber-Matrix Interface on Crack Bridging in Cement Composites. J. Eng. Mech. 1999, 125, 290-299. [CrossRef]

20. Kanda, T.; Li, V.C. Interface Property and Apparent Strength of High-Strength Hydrophilic Fiber in Cement Matrix. J. Mater. Civ. Eng. 1998, 10, 5-13. [CrossRef] 
21. Deák, T.; Czigány, T. Chemical composition and mechanical properties of basalt and glass fibers: A comparison. Text. Res. J. 2009, 79, 645-651. [CrossRef]

22. LoPresto, V.; Leone, C.; De Iorio, I. Mechanical characterisation of basalt fibre reinforced plastic. Compos. Part B Eng. 2011, 42, 717-723. [CrossRef]

23. Sim, J.; Park, C.; Moon, D.Y. Characteristics of basalt fiber as a strengthening material for concrete structures. Compos. Part B Eng. 2005, 36, 504-512. [CrossRef]

24. Dias, D.P.; Thaumaturgo, C. Fracture toughness of geopolymeric concretes reinforced with basalt fibers. Cem. Concr. Compos. 2005, 27, 49-54. [CrossRef]

25. Shafiq, N. Effects of fly ash on chloride migration in concrete and calculation of cover depth required against the corrosion of embedded steel reinforcement. Struct. Concr. 2004, 5, 5-9. [CrossRef]

26. Nuruddin, M.; Quazi, S.; Shafiq, N.; Kusbiantoro, A. Compressive Strength \& Microstructure of Polymeric Concrete Incorporating Fly Ash \& Silica Fume. Can. J. Civ. Eng. 2010, 1, 15-18.

27. EFNARC. Specifications and Guidelines for Self-Consolidating Concrete; European Federation of Suppliers of Specialist Construction Chemicals (EFNARC): Surrey, UK, 2002.

28. Guerini, V.; Conforti, A.; Plizzari, G.; Kawashima, S. Influence of Steel and Macro-Synthetic Fibers on Concrete Properties. Fibers 2018, 6, 47. [CrossRef]

29. Gholampour, A.; Ozbakkaloglu, T. Fiber-reinforced concrete containing ultra high-strength micro steel fibers under active confinement. Constr. Build. Mater. 2018, 187, 299-306. [CrossRef]

30. Marar, K.; Eren, Ö.; Roughani, H. The influence of amount and aspect ratio of fibers on shear behaviour of steel fiber reinforced concrete. KSCE J. Civ. Eng. 2017, 21, 1393-1399. [CrossRef]

31. Balázs, G.L.; Czoboly, O.; Lublóy, É.; Kapitány, K.; Barsi, Á. Observation of steel fibres in concrete with Computed Tomography. Constr. Build. Mater. 2017, 140, 534-541. [CrossRef]

32. Afroughsabet, V.; Biolzi, L.; Ozbakkaloglu, T. High-performance fiber-reinforced concrete: A review. J. Mater. Sci. 2016, 51, 6517-6551. [CrossRef]

33. Yazıc1, H. The effect of silica fume and high-volume Class $\mathrm{C}$ fly ash on mechanical properties, chloride penetration and freeze-thaw resistance of self-compacting concrete. Constr. Build. Mater. 2008, 22, 456-462. [CrossRef]

34. Khatib, J.; Khatib, J. Performance of self-compacting concrete containing fly ash. Constr. Build. Mater. 2008, 22, 1963-1971. [CrossRef]

35. Alyousef, R.; Benjeddou, O.; Khadimallah, M.A.; Mohamed, A.M.; Soussi, C. Study of the Effects of Marble Powder Amount on the Self-Compacting Concretes Properties by Microstructure Analysis on Cement-Marble Powder Pastes. Adv. Civ. Eng. 2018, 2018, 6018613. [CrossRef]

36. Alyousef, R.; Khadimallah, M.A.; Soussi, C.; Benjeddou, O.; Jedidi, M. Experimental and Theoretical Study of a New Technique for Mixing Self-Compacting Concrete with Marble Sludge Grout. Adv. Civ. Eng. 2018, 2018, 3283451. [CrossRef]

37. Alyousef, R. Assessing the Influence of Human Hair on the Mechanical Properties of fibers reinforced Concrete. Int. J. Civ. Eng. Technol. 2018, 9, 459-471.

38. Alyousef, R. Study and Experimental investigation on Performance Self-Compacting Concrete using Different type of Fibers. Rom. J. Mater. 2018, 48, 355-361.

39. Bouzoubaa, N.; Lachemi, M. Self-compacting concrete incorporating high volumes of class F fly ash: Preliminary results. Cem. Concr. Res. 2001, 31, 413-420. [CrossRef]

40. Olivito, R.S.; Zuccarello, F.A. An experimental study on the tensile strength of steel fiber reinforced concrete. Compos. Part B Eng. 2010, 41, 246-255. [CrossRef]

41. Ibrahim, M.H.W.; Hamzah, A.F.; Jamaluddin, N.; Ramadhansyah, P.J.; Fadzil, A.M. Split Tensile Strength on Self-compacting Concrete Containing Coal Bottom Ash Procedia. Soc. Behav. Sci. 2015, 195, 2280-2289. [CrossRef]

42. Jenq, Y.S.; Shah, S.P. Crack propagation in fiber-reinforced concrete. J. Struct. Eng. 1986, 112, 19-34. [CrossRef]

43. Mohamed, A.M.; Osman, M.H.; Smaoui, H.; Ariffin, M.A.M. Permeability and Tensile Strength of Concrete with Arabic Gum Biopolymer. Adv. Civ. Eng. 2017, 2017, 4703841. [CrossRef]

(C) 2019 by the authors. Licensee MDPI, Basel, Switzerland. This article is an open access article distributed under the terms and conditions of the Creative Commons Attribution (CC BY) license (http://creativecommons.org/licenses/by/4.0/). 